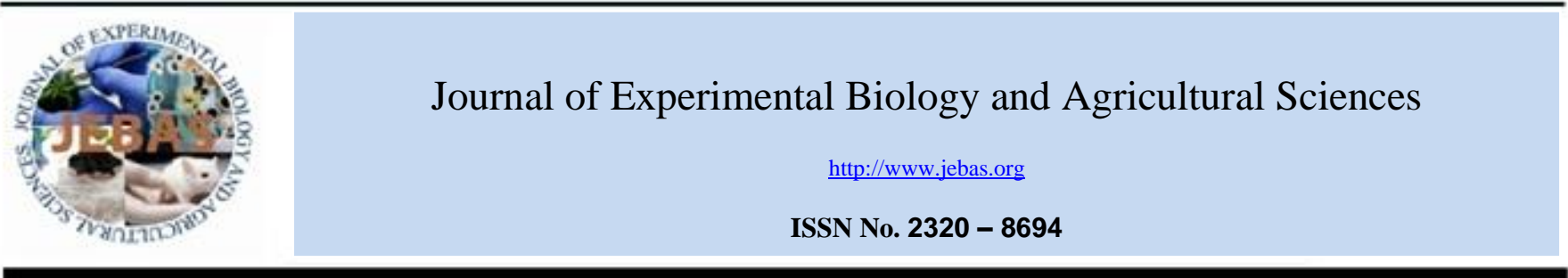

\title{
ALPHA(1)-ADRENOCEPTORS ACTIVATION DECREASES MYOCARDIAL CONTRACTILITY IN NEWBORN RATS
}

\author{
Insaf Ilkhamovich Khabibrakhmanov (D), Anna Mihailovna Kuptsova(D), \\ Nafisa Ilgizovna Ziyatdinova (iD), Nur Mansur (iD), Timur Lvovich Zefirov
}

Department of Human Health, Institute of Fundamental Medicine and Biology, Kazan Federal University, Kazan, Russia

Received - September 25, 2020; Revision - November 16, 2020; Accepted - December 14, 2020

Available Online December 15, 2020

DOI: http://dx.doi.org/ 10.18006/2020.8(Spl-2-AABAS).S322.S326

KEYWORDS
Rat
Myocardial Contractility
Alpha (1)-Adrenergic
Receptors
Methoxamine

\begin{abstract}
Alpha(1)-adrenergic receptors $\left(\alpha_{1}-\mathrm{AR}\right)$ are found in cardiomyocytes, endothelial cells, and smooth muscle cells of humans and animals. Despite the fact that $\alpha_{1}$-AR make up $10 \%$ of the total number of adrenergic receptors, these receptors also involved in the regulation of inotropic and chronotropic functions of the heart. According to some scientists, the effects of $\alpha_{1}$-AR activation are not required for the basal contractile function of the heart while other group of researchers believe that $\alpha_{1}$-AR can be considered as cardioprotective targets; in particular, it is postulated that the $\alpha_{1 \mathrm{~A}}$-subtype of adrenergic receptors can provide significant inotropic support in cardiac pathologies. This study was carried out on 6-7-day-old outbred newborn rat pups to evaluate the effect of alpha(1)-adrenoceptors activation on the myocardial contractility in newborn rats. For this, Alpha ${ }_{1}$-adrenergic receptors were stimulated by the pharmacological drug methoxamine at concentrations of $10^{-9}-10^{-6} \mathrm{~mol}$ and the reaction of the contractile force of the strips of myocardium ventricles and heart atria in response to the agonist was investigated. Results of study revealed that stimulation of alpha ${ }_{1}$-adrenergic receptors, regardless of the methoxamine concentration, led to a negative inotropic reaction of the myocardium of atria and ventricles of newborn rat pups. This study showed unidirectional inotropic responses on rat atrial and ventricular myocardium in response to $\alpha_{1}$ adrenergic receptors stimulation. Methoxamine smoothly reduces the contractile force of the strips of myocardium atria and ventricles. At the same time, the concentration dependence on the inotropic reaction of the myocardium was observed. Results of study suggested that probably $\alpha_{1}$-adrenergic receptors along with the main regulators $\beta$-adrenergic receptors carry out fine tuning of the heart activity.
\end{abstract}

* Corresponding author

E-mail: insaf1201@mail.ru (Insaf Ilkhamovich Khabibrakhmanov)

Peer review under responsibility of Journal of Experimental Biology and Agricultural Sciences.

Production and Hosting by Horizon Publisher India [HPI] (http://www.horizonpublisherindia.in/).

All rights reserved.
All the articles published by Journal of Experimental Biology and Agricultural Sciences are licensed under a Creative Commons Attribution-NonCommercial 4.0 International License Based on a work at www.jebas.org.

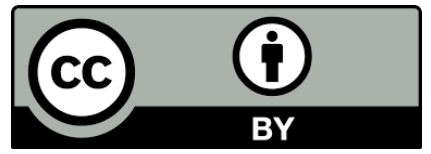




\section{Introduction}

Alpha(1) - adrenergic receptors $\left(\alpha_{1}-\mathrm{AR}\right)$ were identified in the mid1980 s. Using modern research methods, $\alpha_{1}-\mathrm{AR}$ were found in myocardiocytes, endotheliocytes, smooth muscle cells of coronary arteries in humans and animals (Luther et al., 2001). All three receptor subtypes $\left(\alpha_{1 \mathrm{~A}}, \alpha_{1 \mathrm{~B}}, \alpha_{1 \mathrm{D}}\right)$ are found in rat cardiomyocytes, and their density significantly increases in the first week after birth (Nozdrachev et al., 2016). The mRNA of all three subtypes of $\alpha_{1^{-}}$ AR was found in the mouse heart: the expression of $\alpha_{1 \mathrm{~B}}-\mathrm{AR}$ was higher than the total level of $\alpha_{1 \mathrm{~A}}$ and $\alpha_{1 \mathrm{D}}-\mathrm{AR}$. However, the level of $\alpha_{1 \mathrm{~A}}$-adrenergic receptors was slightly higher in the ventricles than in the atria (Zhang et al., 2018). In mice, the $\beta_{1^{-}}$and $\alpha_{1 \mathrm{~B}^{-}}$ subtypes are dominant receptors in heart myocytes and are present in all cells, where $\alpha_{1 \mathrm{~B}}$-AR can have an inhibitory effect on myocardial inotropy. $\alpha_{1 \mathrm{~A}}-\mathrm{AR}$ were found in $60 \%$ of isolated cardiomyocytes, only $20 \%$ of them had a high receptor expression (Myagmar et al., 2017).

In the rabbit myocardium, $\alpha_{1 \mathrm{~A}}-\mathrm{AR}$ are functionally active, mediating a negative inotropic effect in vitro, despite the low level; and $\alpha_{1 \mathrm{~B}}$-subtype of $\mathrm{AR}$ prevails quantitatively and mediates a positive inotropic effect at the level of mRNA and protein (Thomas et al., 2016).

It is generally accepted that $\alpha_{1}$-adrenergic receptors play a major role in the blood pressure control in the cardiovascular system. In addition to smooth muscle contraction, $\alpha_{1}$-adrenergic receptors can induce endothelium-dependent vascular relaxation (Filippi et al., 2001). It has been proven that selective stimulation of $\alpha_{1 \mathrm{~A}}$-AR in the cardiomyocytes potentiates $\mathrm{Ca}^{2+}$-current through $\mathrm{Ca}^{2+}$ - L-type channels. The $\alpha_{1 \mathrm{~A}} \mathrm{AR}$ subtype mediates positive inotropic responses, while $\alpha_{1 \mathrm{~B}}$-AR appears to be associated with a decrease in cardiac contractile function (Micucci et al., 2019). Also, $\alpha_{1 \mathrm{~B}}$-adrenergic receptors can play trophic role and participate in the expression of other receptor subtypes on the cell surface.

$\alpha_{1}$-adrenergic receptors mediate their effects through proteins of the Gq/11 family. In this case, the Gq-protein is decomposed into $\alpha$ - and $\beta \gamma$-subunits and phospholipase $\mathrm{C}$ is activated with the formation of inositol triphosphate $\left(\mathrm{IF}_{3}\right)$ and diacylglycerol. The latter stimulates protein kinase $\mathrm{C}$, while $\mathrm{IF}_{3}$ affects the $\mathrm{IF}_{3}-$ receptors of the endoplasmic reticulum and releases the accumulated calcium. The positive inotropic effect of alpha adrenergic receptor agonists in the rat heart is implemented through the Gs-system and an increase in cAMP production, which inhibits the outflow of potassium ions (Tsirkin \& Korotaeva, 2015).

According to some scientists, the effects of $\alpha_{1}$-AR activation are not required for basal cardiac contractile function. Recently, $\alpha_{1}-\mathrm{AR}$ are considered as cardioprotective targets. In particular, it is postulated that the $\alpha_{1 \mathrm{~A}}$-adrenergic receptor subtype can provide significant inotropic support in different heart diseases (Nozdrachev et al., 2016).

Previously, it was shown that nonselective stimulation of $\alpha_{1}$ adrenergic receptors with metoxamine $\left(10^{-9}\right.$ and $\left.10^{-8} \mathrm{M}\right)$ inhibits the frequency (Zefirov et al., 2016) and the strength of isolated heart contractions (Zefirov et al., 2018a), and it was also revealed that methoxamine causes a decrease in the contractile response within the experiments performed on the strips of myocardium ventricles and atria of adult rats (Zefirov et al., 2018b). At the same time, selective stimulation of the $\alpha_{1 \mathrm{~A}}$ receptor subtype by the A-61603 agonist (regardless of concentration) caused negative inotropy of the ventricles in 20-week-old rats, but positively induced the ventricular myocardium contractility in newborn animals. Moreover, the severity and duration of myocardial inotropic responses depended on the agonist concentration (Khabibrakhmanov et al., 2019).

The results of numerous researchers indicated that the heterogeneity of myocardial inotropic responses to the activation of alpha-adrenergic receptors in different species and age groups of animals. Further, Nozdrachev et al. (2016) also specified an increase in the density of the studied heart receptors at the early stages of postnatal development. Based on the foregoing, current study formulated a hypothesis about the presence of age-related features in the inotropic responses of the myocardium to stimulation of alpha ${ }_{1}$-adrenergic receptors in newborn rat pups. The aim of this study was to evaluate the inotropic effect of stimulation of alpha ${ }_{1}$-adrenergic receptors in the myocardium ventricles and atria of 1-week-old rat pups.

\section{Materials and Methods}

The study was carried out on 6-7-day-old outbred newborn rat pups. For anaesthetize the rate $25 \%$ urethane solution (dose: 800 $\mathrm{mg} / \mathrm{kg}$, intraperitoneally) was used. Myocardial strips were excised from the right atrium and right ventricle of the heart and placed in a bath with a process solution (composition, in $\mathrm{g} / \mathrm{l}$ : $\mathrm{NaC} 1-7.6$; $\mathrm{KC} 1-0.42 ; \mathrm{NaH}_{2} \mathrm{PO}_{4}-0.07 ; \mathrm{MgCl}_{2}-0.104 ; \mathrm{CaCl}_{2}-0.198$; $\mathrm{NaHCO}_{3}-1.69 ; \mathrm{C}_{6} \mathrm{H}_{12} \mathrm{O}_{6}-1.98$; Trizmabase -0.25 ) by fixing them vertically from above to the contractile force registration sensor, and below to the holder. The heart myocardium strips were stimulated by an electrical signal through silver ring electrodes (frequency - 6 stimuli/min, amplitude - $10 \mathrm{mV}$, duration - $5 \mathrm{~ms}$ ). After this myocardium strips were immersed in the solution and the thread tension was adjusted, their fixation was followed by an elaboration period (30-40 minutes). After 5 minute of elaboration, the initial values of the contractile force of the strips were recorded. Further, we recorded the inotropic reaction of the atrial and ventricular myocardium in response to non-selective 
stimulation of $\alpha_{1}$-adrenergic receptors. For non-selective stimulation of $\alpha 1$-adrenergic receptors, methoxamine hydrochloride $(\mathrm{MH})$ (Sigma) drug was used in the concentration range of $10^{-9}-10^{-6} \mathrm{~mol} / \mathrm{L}$. Changes in the contractile force $(\mathrm{F}$, expressed in grams $(\mathrm{g})$ ) of myocardial strips after substance addition were evaluated as inotropic effects of methoxamine and analyzed in relation to baseline values. The statistical analysis of the current study was carried out using the original software "AcKnowledge 4.1", MB-150 experimental installation (BIOPAC Systems, USA). The reliability of changes was determined by the Student's test at $*_{-}-\mathrm{p}<0.05 ; * *-\mathrm{p}<0.01, * * *-\mathrm{p}<0.001$.

\section{Results and Discussion}

\subsection{Effects of methoxamine on contractility of atria myocardium strips}

The initial values of the atrial contractile force in newborn rat pups were in the range of $0.0213-0.0299 \mathrm{~g}$. While the stimulation of $\alpha 1$-adrenergic receptors with a non-selective agonist metoxamine with a concentration of $10^{-9} \mathrm{~mol}$ caused a decrease in the contractile force of atrial myocardial strips $(n=6)$ in newborn rat pups from $0.0299 \pm 0.007 \mathrm{~g}$ to $0.0225 \pm 0.005 \mathrm{~g}$ ( $\mathrm{p}<0.05)$, and the negative inotropic effect was $25 \%$ (Figure 1). While in response to the metoxamine effect at a concentration of $10^{-8} \mathrm{~mol}$, the contractile force of atrial myocardial stripes $(n=6)$ gradually decreased from $0.0276 \pm 0.006 \mathrm{~g}$ to $0.0222 \pm 0.004 \mathrm{~g}$ ( $\mathrm{p}<0.05$ ), the change was $20 \%$.

Further, MH introduction at a concentration of $10^{-7} \mathrm{~mol}$ had a negative inotropic effect on the atrial myocardium stripes $(n=6)$ of 1-week-old rat pups, which reached a maximum effect by the 20th minute of the agonist action. At the same time, the contractile force values changed from $0.0237 \pm 0.002 \mathrm{~g}$ to $0.0171 \pm 0.0009 \mathrm{~g}$ ( $\mathrm{p}$
$<0.01$ ) and the effect was $29 \%$ (Figure 1). A similar dynamics of atrial contractility was also observed under the effect of methoxamine at a concentration of $10^{-6} \mathrm{~mol}(\mathrm{n}=6)$ and the contractile force decreased from $0.021 \pm 0.001 \mathrm{~g}$ to $0.015 \pm 0.0008 \mathrm{~g}$ which is $31 \%(\mathrm{p}<0.001)$. This series of experiments showed that an increase in the negative inotropic reaction of the atrial myocardium of 1-week-old rat pups was observed with an increase in the agonist concentration.

\subsection{Effects of methoxamine on contractility of ventricular myocardium strips}

The initial values of the contractile force of the ventricular myocardium strips was in the range of $0.0280-0.0393 \mathrm{~g}$. The contractile force of the ventricular myocardium stripes $(n=7)$ on newborn rat pups in response to the metoxamine effects at a concentration of $10^{-9}$ mol gradually decreased from $0.0352 \pm 0.0044$ $\mathrm{g}$ to $0.0301 \pm 0.004 \mathrm{~g}(\mathrm{p}<0.05)$ with a change of $15 \%$ (Figure 2). While addition of $10^{-8} \mathrm{~mol}$ methoxamine, the contractile force of the ventricular myocardium of newborn rat pups decreased by $20 \%$ $(\mathrm{p}<0.01)$. The indicators of myocardial inotropy changed from $0.0393 \pm 0.0034 \mathrm{~g}$ to $0.0314 \pm 0.0036 \mathrm{~g}$.

Stimulation of $\alpha_{1}$-AR by the methoxamine application at a concentration of $10^{-7}$ mol caused the maximum negative inotropic reaction of the ventricular myocardium of newborn rat pups in comparison with other concentrations. The decrease in the contractile force of the ventricular myocardium from $0.0342 \pm 0.0034 \mathrm{~g}$ to $0.0251 \pm 0.0031 \mathrm{~g}(\mathrm{p}<0.001)(\mathrm{n}=7)$ lasted until the 20th minute of the methoxamine affect $\left(10^{-7} \mathrm{~mol}\right)$ and the effect was $27 \%$.

MH administration at $10^{-6}$ mol reduced the contractile force of the ventricular myocardium in rat pups from $0.0282 \pm 0.0018 \mathrm{~g}$ to

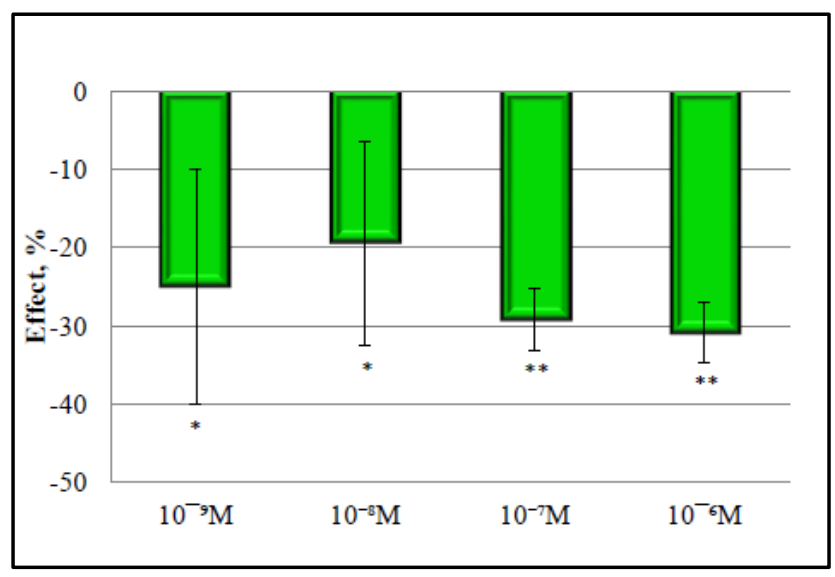

Figure 1 Effects of metoxamine on the contractile force of atrial myocardial strips in 1-week-old rats (Note:* represent significance level at $\mathrm{p}<0.05 ; * *$ represent significance level at $\mathrm{p}<0.01$ )

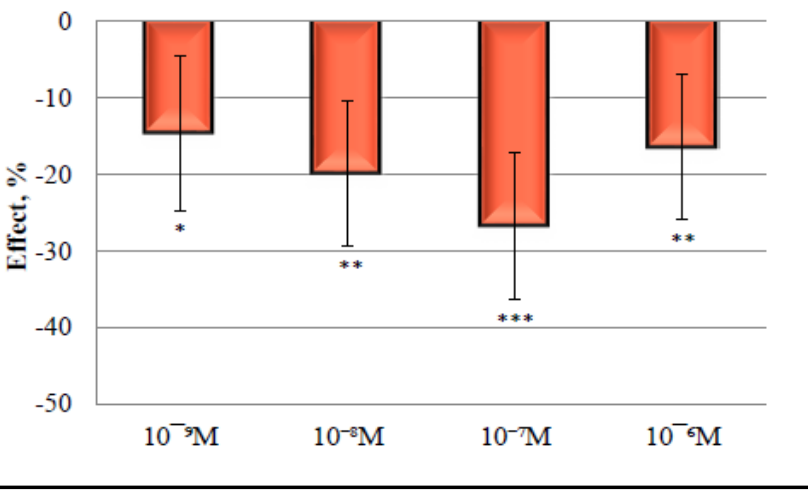

Figure 2 Effects of methoxamine on the contractile force of the ventricular myocardium strips of 1 -week-old rats. Note: ${ }^{*}-\mathrm{p}<0.05 ; * *-\mathrm{p}<0.01 ; * * *-\mathrm{p}<0.001$. 
$0.0233 \pm 0.0025 \mathrm{~g}(\mathrm{p}<0.01)$, the change in contractility was $17 \%$ (Figure 2).

Results of study suggested that the stimulation of alpha(1)adrenergic receptors, regardless of the concentration of the agonist metoxamine, causes unidirectional inotropic effects on the myocardium of newborn rat pups. Methoxamine smoothly reduces the contractile force of the strips of myocardium atria and ventricles. At the same time, the concentration dependent inotropic reaction of the myocardium was also obesrved. Methoxamine caused the strongest decrease in the contractile force of the atrial myocardium. These results are in agreement with the findings of Zefirov et al. (2018a) those who reported that activation of alpha(1)-adrenergic receptors by methoxamine has a negative inotropic effect on the heart of 20-week-old rats. Further, this study did not revealed age-related features in the inotropic response of the myocardium in newborn rat pups on stimulation of alpha 1adrenergic receptors.

The negative inotropic effect on the heart can be implemented mainly through the $\alpha_{1 \mathrm{~B}}$-adrenergic receptor subtype. The mechanisms of the negative inotropic effect on $\alpha_{1}$-AR activation might be because of an increase in the synthesis of nitric oxide (II), activation of the $\mathrm{Na}^{+} / \mathrm{Ca}^{+}$metabolic process, an increase in the outbound $\mathrm{K}^{+}$current, inhibition of $\mathrm{Ca}^{2+}$ channels of L-type, a decrease in the sensitivity of myofilaments to $\mathrm{Ca}^{2+}$ etc. Negative inotropy may also depend on the activity of protein kinase D, which reduces the contractile force by phosphorylation of troponin I (Tsirkin \& Korotaeva, 2015). Probably, $\alpha 1$-adrenergic receptors, along with the main regulators - $\beta$-adrenergic receptors, carry out more fine tuning of the heart activity.

\section{Conclusion}

Methoxamine, an agonist of alpha ${ }_{1}$-adrenergic receptors led only to a unidirectional negative inotropic reaction of the myocardial strips of both the heart atria and the heart ventricles of newborn rat pups at the concentrations studied by us. At the same time, we observed the concentration dependence of the inotropic reaction of the myocardium.

\section{Acknowledgements}

This study was prepared in accordance with the Russian state program of competitive growth of Kazan Federal University and supported by the RFBR and Government of the Republic of № 18 44-160022.

\section{Conflict Of Interest}

Authors would hereby like to declare that there is no conflict of interests that could possibly arise.

\section{References}

Filippi S, Parenti A, Donnini S, Granger HJ, Fazzini A, Ledda F (2001) Alpha(1D)-adrenoceptors cause endothelium-dependent vasodilatation in the rat mesenteric vascular bed. Journal of Pharmacology and Experimental Therapeutics 296: 869-875.

Khabibrakhmanov II, Ziyatdinova NI, Khisamieva LI, Biktemirova RG, Zefirov TL (2019) Alpha(1A)-adrenoreceptor participation in myocardial contractility regulation among newborn rats. Plant Archives 19(2):2188-92.

Luther H, Podlowski S, Schulze W, Morwinski R, Buchwalow I, Baumann G, Wallukat G (2001) Expression of alpha ${ }_{1}$-adrenergic receptor subtypes in heart cell culture. Molecular and Cellular Biochemistry 224(1-2):69-79.

Micucci M, Chiarini A, Budriesi R (2019) Neutral/negative $\alpha_{1}$-AR antagonists and calcium channel blockers at comparison in functional tests on guinea-pig smooth muscle and myocardium. Pharmacological Reports 71(1): 128-132.

Myagmar BE, Flynn JM, Cowley PM, Swigart PM, Montgomery MD, Thai K, Nair D, Gupta R, Deng DX, Hosoda C, Melov S, Baker AJ, Simpson PC (2017) Adrenergic Receptors in Individual Ventricular Myocytes: The Beta-1 and Alpha-1B Are in All Cells, the Alpha-1A Is in a Subpopulation, and the Beta-2 and Beta-3 Are Mostly Absent. Circulation Research 120(7): 1103-15. doi: 10.1161/CIRCRESAHA.117.310520.

Nozdrachev AD, Tsirkin VI, KorotaevaYB (2016) The role of alpha1-adrenergic receptors in the heart activity of humans and animals. Part 2. Russian Journal of Physiology named after I.M. Sechenov 102(3): 262-275.

Thomas RC, Cowley PM, Singh A, Myagmar BE, Swigart PM, Baker AJ, Simpson PC (2016) The Alpha-1A Adrenergic Receptor in the Rabbit Heart. PLoS ONE 11(6): e0155238.

Tsirkin VI, Korotaeva YV (2015) Participation of protein kinases A, B, C, D in the regulation of cardiomyocyte contractility (Review. Message I). Biomedical Research Journal 2: 53-61.

Zefirov TL, Khabibrakhmanov II, Valeeva YV, Zefirova YT, ZiyatdinovaNI (2018a) Stimulation of $\alpha 1$-adrenergic receptors inhibits contractility of the rat myocardium. Scientific Notes of the Kazan University "Natural sciences" 160(4): 613-620.

Zefirov TL, Khabibrakhmanov II, Zefirova JT, Ziyatdinova NI (2018b) The influence of methoxamine on the isolated heart chronotropy and inotropy. European Journal of Clinical Investigation 48(1): 139. 
Zefirov TL, Khabibrakhmanov II, Ziyatdinova NI, Zefirov AL Zhang S, Takahashi R, Yamashita N, Teraoka H, Kitazawa T (2016) Features of the effect of stimulation of $\alpha 1$-adrenergic (2018) Alpha ${ }_{1 \mathrm{~B}}$-adrenoceptor-mediated positive inotropic and receptors on the isolated heart of rats. Bulletin of the Experimental Biology and Medicine 162 (1): 4-6. positive chronotropic actions in the mouse atrium. European Journal of Pharmacology 839: 82-88. 